\title{
Analysis of the state of preservation the historic arcaded houses in Vistula Delta listed in the National Inventory of Historical Monuments
}

\author{
Tomasz Zybała \\ Faculty of Civil and Environmental Engineering, Gdańsk University of Technology; \\ 11/12 G. Narutowicza St., 80-233 Gdańsk, Poland; \\ tomasz.zybala@pg.edu.pl (iD 0000-0001-9186-4960
}

\begin{abstract}
Historic arcaded houses are part of the material heritage of the Vistula Delta. Unfortunately, their number is decreasing year by year. The article is the result of a query of available sources and field research carried out by the author in 2015-2020. The paper presents the current state of preservation the historic arcaded houses in Vistula Delta listed in the National Inventory of Historical Monuments. Criteria for the selection of test objects are described. The author has prepared a tabular list of arcaded houses with information about their location, type according to Kloeppel statistics, date of construction, technical condition and functions. The summary of the analysis are pie charts with a statistical presentation of the data collected by the author during the research.
\end{abstract}

Keywords: arcaded houses, Vistula Delta, historical monuments of the Vistula Delta

\section{Introduction}

The arcaded houses were a common element of the wooden architecture of former Poland, Silesia, Pomerania and Prussia. They differed from each other in size, shape, structure and interior layout. The main reason for the use of columns in the construction of buildings was to create a roofed space; they served as a cover for the entrance door against precipitation, as well as a rest area. The arcades reflected the owner's property status, lifestyle, ethnicity, as well as the development of carpentry techniques in a given period. Arcades were found not only in residential buildings, but also in churches, town halls, granaries and forges [1], [2].

The arcaded houses from the area of Vistula Delta (also called in Polish Żuławy Wiślane) are the most characteristic, historic residential buildings in the region [3], [4]. They are a distinguishing feature of the cultural environment of the Vistula Delta. In the past, residential houses with columns were a permanent element of the architecture of the village of Żuławy [5]. 
Currently, they are few and scattered examples of the old architecture of the Vistula Delta. The process of degradation of arcaded houses is progressing [6], [7]. Actually, the main factors reducing the number of arcaded houses in Żuławy are insufficient care of the owners to keep them in good technical condition and the lack of funds for construction and conservation works.

The aim of the article is to make a quantitative statement of the preserved historic arcaded houses from the Vistula Delta (as of 2020). The article is also a summary of the field research carried out by the author in 2015-2020 and update and supplement to the results made by other researchers.

\section{State of research}

The available literature describing the arcaded houses located in Vistula Delta can be divided into items created before 1945, mainly German², and those published after the end of the war, mostly Polish.

The first scientific studies focused mainly on the architectural form of arcaded houses. Architectural historians have included descriptions of only some of the houses from the Vistula Delta [8], [9]. Another source of information about the number of houses existing before 1945 are the lists and reports of German conservators[10], [11], [12]. However, these works do not contain information about all arcaded houses that existed before the war in Żuławy.

The first study that gives an approximate number of preserved arcaded houses from the Vistula Delta is the post-war study by Jerzy Stankiewicz ${ }^{3}$, who defined the state of preservation at 131 objects, but it is incomplete ${ }^{4}$ [3]. In the 1960s, descriptions by Lech Krzyżanowski were created, with extensive photographic documentation of the houses [13]. Information on the state of preservation of the historic structure of settlements, including arcaded houses, from the 1980s was included in doctoral dissertation on the development and typology of the Żuławy village by Bogna Lipińska [14]. The latest work that discusses the state of preservation of arcaded houses in Vistula Delta is the doctoral dissertation of Marta Koperska-Kośmicka [7] published in 2020 [15]. The author has compiled a list of historic arcaded houses listed in the National Inventory of Historical Monuments from the area of Żuławy Wiślane and a part of the Elbląg Upland (as of 2013). In it, she presented a table with 63 objects. It also included houses with a recessed arcades, monuments that have lost their arcade, farm buildings, as well as objects that did not exist during the preparation of the work or they were in ruins. Marta Koperska-Kośmicka in her dissertation also described the process of degradation of arcaded buildings in the area of the Vistula Delta in the $20^{\text {th }}$ century. The analysis also included those houses that were not listed in the register of monuments. The state of preservation was determined at 108 objects (as of 2013).

1 The author visited all the places with arcaded houses listed in the National Inventory of Historical Monuments of the Pomeranian Voivodeship [18] and Warmian-Masurian Voivodeship [19]. During the research, the author made photographic documentation and interviewed the owners of the monuments.

2 Before the second world war, arcaded houses in Vistula Delta were also the subject of research by Poles: Gerard Ciołek [29] and Władysława Łęga [30].

3 Jerzy Stankiewicz (1923-1994) architectural historian, professor at the Gdańsk University of Technology.

4 It is not an exact number. The list was not complete because it did not include all the preserved arcaded houses. The reasons were transport problems and the lack of sufficient time to carry out detailed field research. 
Today, there is no current list of the existing historic arcaded houses of the Vistula Delta listed in the National Inventory of Historical Monuments ${ }^{5}$. There are also no collective studies specifying their technical condition, date of construction or type ${ }^{6}$. There are also no updates and supplements to the inspection of historical buildings made by other researchers dealing with arcaded houses in Żuławy. The lack of the above-mentioned analyses prompted the author of the article to start field research and perform a query of available sources.

\section{Research method}

The article uses a varied research method containing elements of three methods: historical-interpretative, quantitative and statistical [16], [17]. The basis for starting work on the state of preservation was a library and archival query of items describing historic arcaded houses of the Vistula Delta. The author got acquainted with the collections of: the historical section of the Main Library of the Gdańsk University of Technology, the archives of the National Heritage Board of Poland in Gdańsk, the Main Library of the University of Gdańsk, the Żuławy Museum in Nowy Dwór Gdański, the C.K. Norwid Library in Elbląg7 and available internet sources [18], [19], [20]. The article presents a numerical list of preserved, historic arcaded houses from the Vistula Delta. The author gives the results of his research in the table (tab. 1). The houses have been arranged chronologically. The table also contains information about the type of house and the province in which the monument is located. The last column contains information about the technical condition, construction and conservation works in recent years and the current function. The summary of quantitative research is a graphical representation of the results in pie charts. They present a statistical view of the data collected by the author during field research (2015-2020).

\section{Research field - criteria for selecting objects for research}

The author's research area is a low-lying plain - the Vistula Delta with an area of $2460 \mathrm{~km}^{2}$, also known as Żuławy Wiślane [21], [22]. The following are distinguished: Żuławy Gdańskie located west of the Vistula, Żuławy Malborskie between the Vistula and the Nogat, and Żuławy Elbląskie east of the Nogat and south of Elbląg. The list does not include arcaded houses from the Elbląg Upland, the Iławskie Lakeland, the Walichnowska Lowlands, the Starogard Lakeland and the Kashubian Lakeland [21].

The subject of the author's research are objects entered in the register of monuments ${ }^{8}$ [18], [19], considered the most valuable and representative. In accordance with the Act on the protection and care of monuments: ,monument - real estate or movable property, their parts or complexes, being a work of man or related to his activity and being a testimony of a bygone era or events whose preservation is in the public interest due to their historical, artistic or scientific value" [23]. Hence, by the decision of the conservation authorities, objects

The author takes into account only those houses that have a arcade.

6 Status for 2020, summary taking into account the losses of the last 5 years (duration of the author's field research).

7 Footnotes to individual items are given in the text.

8 There are arcaded houses in Vistula Delta which are not listed in the register of monuments. Examples are houses in: Świerki no. 28, Brzózki no. 13, Cedry Małe no. 7 (ruin), Cyganek-Żelichowo no. 31a or a house with a built-up arcade in Marynowy no. 7, which by some internet sources is incorrectly defined as an object listed in the register of monuments [18]. Objects not included in the list of historical monuments may be the basis for the preparation of a another article. 
that meet the above-mentioned criteria are listed in the register. In addition, each arcaded house entered in the register of monuments has its own record card, where it is possible to find information about its history, architecture, and repairs ${ }^{9}$. Confirmed information about technical interventions is important for the author, who, in his research, focuses on the technical and conservation issues of historic arcaded houses construction [24], [25], [26].

The group of objects analysed by the author are arcaded residential houses. According to Kloeppel's statistics, established in the 1920s (confirmed after the war by Stankiewicz), we distinguish three basic types from the Vistula Delta: type I, type II and type III [3], [8] (Fig. 1). The oldest form is type I. It is a house on a rectangular plan, with columns located in the gable wall (Fig. 1a). In the $17^{\text {th }}$ century, type II began to appear (Fig. 1b), a house with pillars located in the gable wall, with an additional side wing. The arcade of houses type I and II were based on 7, 8 or 9 pillars. Additionally, in both types there is a storey on the entire plan of the building. Type III appears in the second half of the $18^{\text {th }}$ century (Fig. 1d, e). It is a house with a central portico perpendicular to the ridge. The first floor is kept only in the portico. The number of columns is from 4 to $7^{10}$ in the front. The use of additional pillars reduces the depth of the portico ${ }^{11}$. In the development of the architectural form of the arcaded houses in Żuławy there is also an intermediate type, between II and III (Fig. 1c). It is characterized by a central portico supported on columns, perpendicular to the ridge, the number of pillars is 8 . The storey is maintained throughout the building plan or there is a mansard roof.

The research field has been narrowed down to the above-mentioned group of houses with aportico in the gable wall or central portico perpendicular to the ridge ${ }^{12}$. In the mid-nineteenth century, there was a significant reduction in the avant-corps based on columns in the houses (Fig. 1f). Over time, the portico transforms into a decorative porch, which only refers to the old and traditional form of the house in the Vistula Delta ${ }^{13}$. Therefore, the group of objects analyzed by the author are the oldest arcaded houses. Their structures reach large spans ${ }^{14}$ and sizes of construction elements ${ }^{15}$. The temporal scope of the preserved objects belonging to the traditional arcaded houses in Żuławy is from the $17^{\text {th }}$ to the 2 nd half of the $19^{\text {th }}$ century (tab. 1).

The last factor in selecting monuments for field research was their primary function. In the past, arcaded houses had a residential role ${ }^{16}$. Forges cannot be included in this group ${ }^{17}$ and farm buildings with arcade too ${ }^{18}$, even though they are listed in the register of monuments.

9 Each technical intervention in a historic building must be approved by the Provincial Conservator of Monuments. Information about renovations and repairs is placed in the Architecture and Building Historical Monument record [31], [32].

10 For example, arcaded house in Koszwały.

11 For example, a house in Orłowo (1 Wspólna Street), has 4 pillars in the front and 4 side pillars.

12 In the research, the author does not take into account other forms of arcaded houses in the Vistula Delta (for example, a house with a recessed arcade in Pruszcz Gdański - 6 Krótka Street).

13 For example, a house in Tuja built in 1871. (the date is above the main entrance to the facility).

14 For example a house in Nowa Kościelnica, the span of roof structure is $11.80 \mathrm{~m}$ [25].

15 The building structure is then more loaded and the internal forces are greater. This is the material for the development of mechanical analyzes, as well as for the recognition of the technology of making these constructions.

16 The oldest houses, type I and II, also had a storage function. Grain was stored in the attic.

17 The arcaded forge in Gdańsk Orunia, 10 Gościnna Street.

18 The arcaded barn in Krzewsk no. 29. 


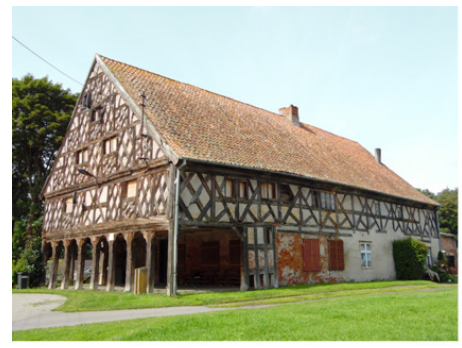

a)

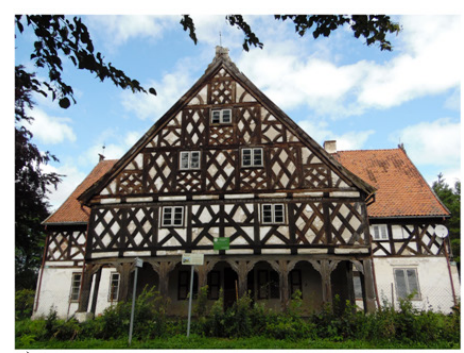

c)

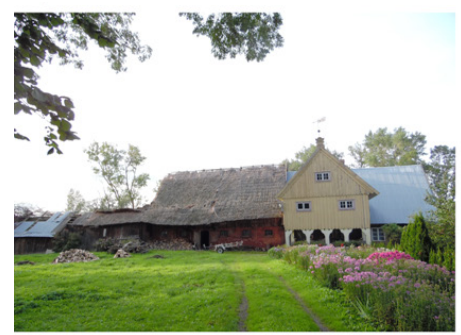

e)

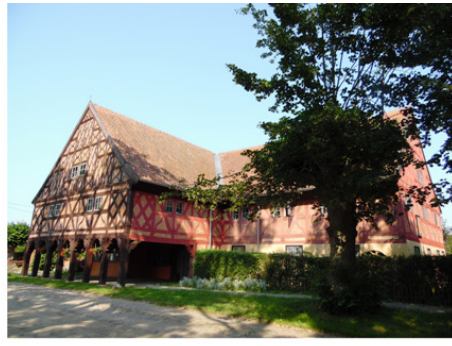

b)

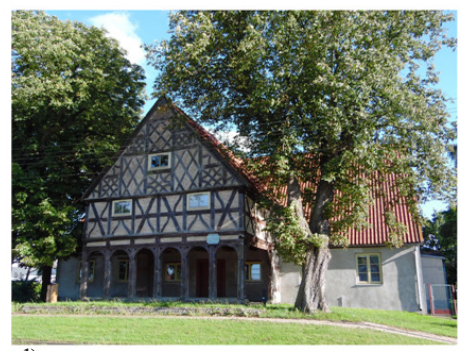

d)

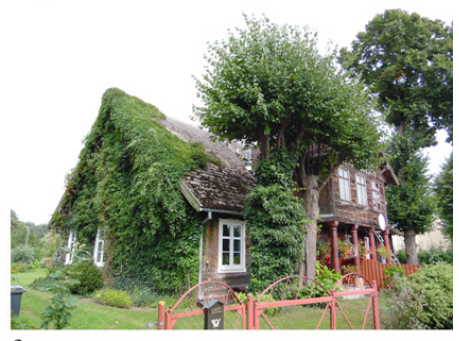

f)

Fig. 1. Types of arcaded houses: a) type I house in Klecie, b) type II house in Trutnowy, c) type II-III house in Stalewo no.14, d) type III house in Koszwały, e) type III house in Markusy, f) type III house in Mikoszewo no. 68 (photo by the author)

\section{Preserved arcaded houses - quantitative specification}

The basis for the field research were the National Inventory of Historical Monuments of the Pomeranian Voivodeship [18] and the Warmian-Masurian Voivodeship [19] ${ }^{19}$. The analysis of both collections shows 74 existing arcaded houses ${ }^{20}$. After taking into account the territorial scope (houses located in the Vistula Delta), the number of monuments decreased to 51. In the Pomeranian Voivodship, out of 42, there were 41 houses, and in the Warmian-Masurian Voivodship, out of 32 houses remained 10.

During the field research, the author, upon arrival at the site, stated that despite being entered in the register of monuments, some objects do not exist or are destroyed. These are

19 Both registers are from 2015, when the author began work on determining the state of preservation of historic arcaded houses.

20 The register also includes arcaded houses that have undergone destruction. Next to a given item there is an annotation "does not exist" (for example, the arcaded house in Orłowo no. 27 [18]). 
houses in Lasowice Małe (Fig. 2a) $)^{21}$, Kławki (Fig. 2b) 22 $^{2}$ and Świerki (Fig. 2c) 2 $^{23}$. The list of historical monuments (as of 2015) also includes an arcaded house in Złotów, which burned down in $2014^{24}$.

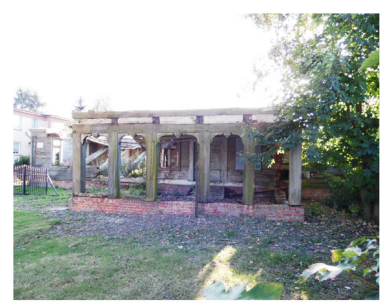

a)

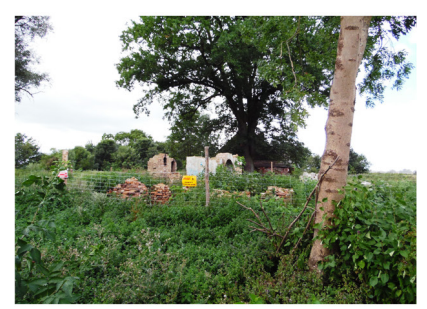

b)

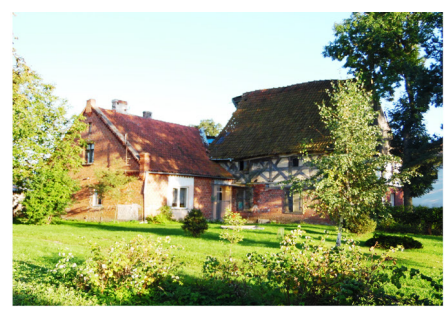

c)

Fig. 2. Destruction of arcaded houses: a) Lasowice Małe, b) Kławki, c) Świerki (photo by the author)

There are also irregularities in the register of monuments, in the village of Krzewsk there is an outbuilding with an arcade in the gable wall, incorrectly classified as an arcaded house [19].

During five years of research, the state of preservation decreased by one monument (Fig. 3a). In 2017, the house in Izbiska from 1778 was completely destroyed ${ }^{25}$. In May 2017, as a result of a strong wind, the arcade collapsed (Fig. 3b), in November 2017 the house burned down. No attempt was made to rebuild it (Fig. 3c, d) ${ }^{26}$.

21 The house is in ruins. Only part of the ground floor of the building has survived (as of 2016).

22 The house was demolished, in 2016 there was only a chimney.

23 The house is partially destroyed (1/3 of the roof collapsed).

24 The house was rebuilt after a fire, but it lost its historic value irretrievably. Its construction is new.

25 In 2016, the author measured the geometry of the break as well as the height and cross-sections of the columns.

26 In 2020, only the foundations of the house and construction rubble from its demolition are left. 


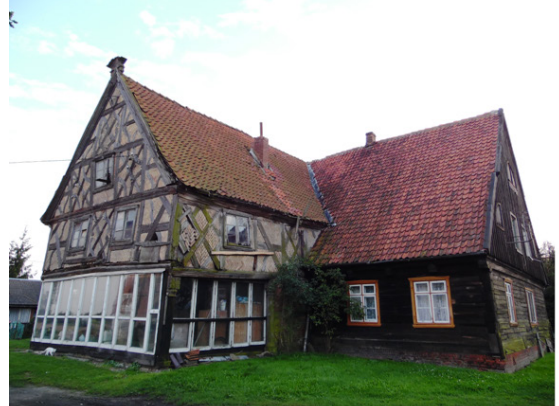

a)

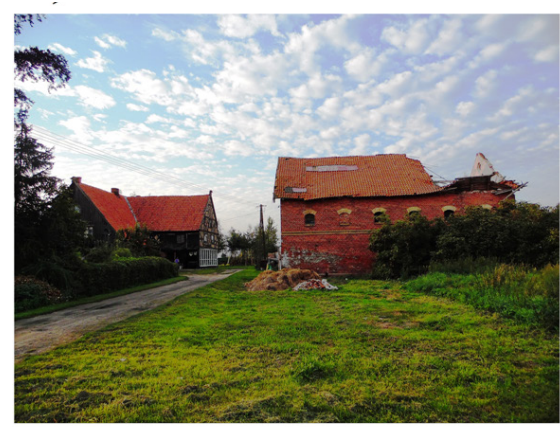

c)

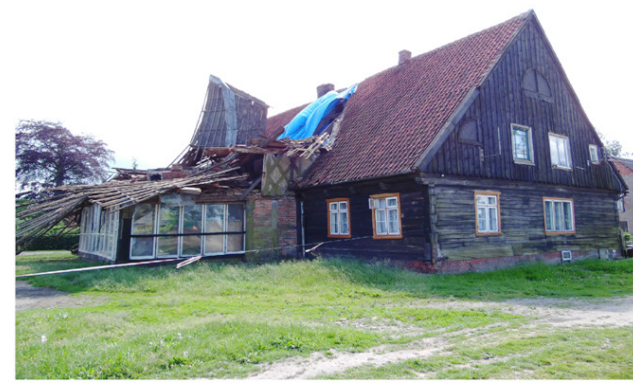

b)

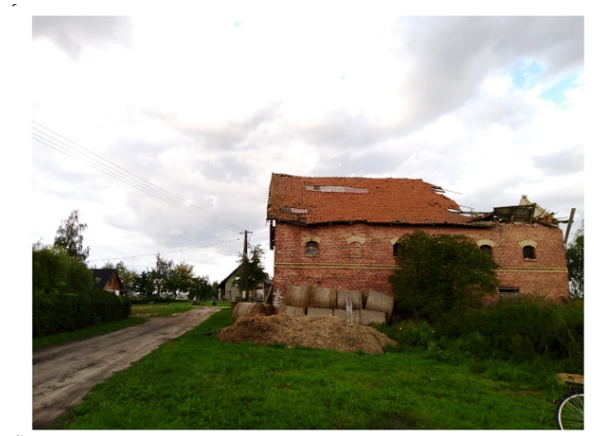

d)

Fig. 3. Destruction of the arcaded house in Izbiska: a) August 2016, b) June 2017, c) view of the farm August 2016, d) view of the farm - September 2020 (photo by the author)

Some houses have lost their avant-corps as a result of breakdowns or reconstructions and are no longer arcaded houses. Examples of such activities are houses in Marynowe no. 23/25 (Fig. 4a) and Stalewo no. 18 (Fig. 4b) ${ }^{27}$.

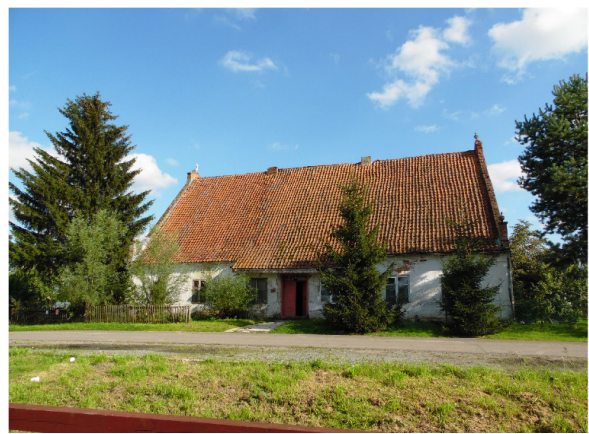

a)

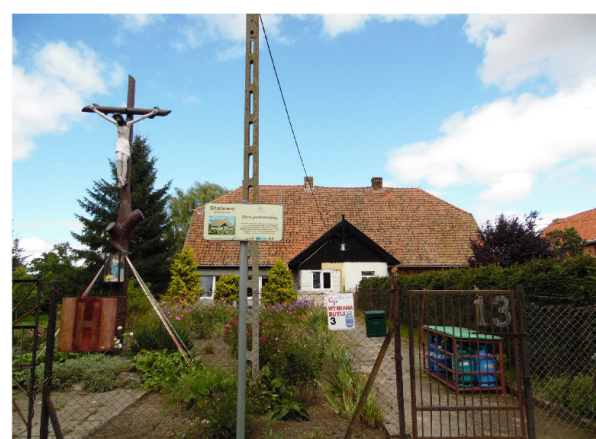

b)

Fig. 4. Houses in: a) Maynowy no. 23/25 b) Stalewo no. 18 (photo by the author)

27 The house was heavily rebuilt, completely lost its features of an arcaded house, decorations were removed. 
The above-described situations resulted in the reduction of the research field by 8 objects. the number of monuments included in the analysis decreased from 51 to 43.

The latest register of monuments (as of 2021) [27], [28] does not show any major changes from 2016, when the author began field research. The list was reduced only by the one arcaded house in Izbiska.

The results of the author's research are presented in a table containing: addresses of arcaded houses, voivodeship , classification according to Kloeppel's statistics, date of construction, comments on the technical condition ${ }^{28}$, the current function of the monument, repairs and additional observations of the author (Table 1).

Table 1. The current state of historic arcaded houses, as of 2020

\begin{tabular}{|c|c|c|c|c|c|}
\hline No & localization & voivodeship & $\begin{array}{l}\text { House type } \\
\text { according } \\
\text { to Kloeppel } \\
\text { statistics }\end{array}$ & $\begin{array}{l}\text { date of } \\
\text { construction }\end{array}$ & remarks \\
\hline 1 & $\begin{array}{l}\text { Gdańsk } \\
\text { Lipce, } 297 \text { St. } \\
\text { Wojciech Tract }\end{array}$ & Pomeranian & I & $1600[1]^{29}$ & $\begin{array}{l}\text { technical condition of the } \\
\text { house: very good, the oldest } \\
\text { preserved arcaded house } \\
\text { in Vistula Delta, renovated } \\
\text { in } 2005 \text {, currently used as } \\
\text { a hostel }\end{array}$ \\
\hline 2 & $\begin{array}{l}\text { Trutnowy, } \\
7 \text { Podcieniowa } \\
\text { Street (Fig. 1b) }\end{array}$ & Pomeranian & II & 1720 & $\begin{array}{l}\text { technical condition: very good, } \\
\text { currently the house is a resi- } \\
\text { dential building, it houses the } \\
\text { seat of the Gdańsk Żuławy } \\
\text { Association and an art gallery }\end{array}$ \\
\hline 3 & Miłocin 8 & Pomeranian & II & 1731 & $\begin{array}{l}\text { technical condition: very } \\
\text { good, house after complete } \\
\text { renovation in } 2011 \text {, currently } \\
\text { a multi-family building, in the } \\
\text { attic there is a conference and } \\
\text { exhibition room for a local } \\
\text { cultural centre }\end{array}$ \\
\hline 4 & Lubieszewo 50 & Pomeranian & III & 1747 & $\begin{array}{l}\text { technical condition: sufficient, } \\
\text { residential house }\end{array}$ \\
\hline 5 & Rozgart 24 & $\begin{array}{l}\text { Warmia - } \\
\text { Masuria }\end{array}$ & III & 1749 & $\begin{array}{l}\text { technical condition: good, } \\
\text { residential house }\end{array}$ \\
\hline
\end{tabular}

28 The technical condition was determined on the basis of the job experience of the author who worked in the technical department of Gdański Zarząd Nieruchomości Komunalnych. A four-level scale describes the general technical state of the structure: walls, staircases, ceilings, roof trusses and roofing (very good condition means no remarks, good condition means the presence of minor defects that do not endanger the inhabitants, some building elements may require replacement in the future or repair, sufficient condition means that the building requires renovation but it does not threaten a construction disaster, insufficient condition means that there is a high risk of a construction disaster and requires urgent renovation works). In the article, the author does not assess the correctness of the technical interventions made in relation to the principles of monument conservation.

29 The exact date of the construction of the arcaded house in Gdańsk Lipce is unknown. Researchers describing the monument give the following periods: Otto Kloeppel 1600r.[8], Jerzy Stankiewicz $17^{\text {th }}$ century [3], Ignacy Tłoczek 1600 [1], Lech Krzyżanowski $17^{\text {th }}$ century [33], Tomasz Ważny 1572 [34], Marta Koperska-Kośmicka end of XVIth century [7]. 
Analysis of the state of preservation the historic arcaded houses in Vistula Delta...

\begin{tabular}{|c|c|c|c|c|c|}
\hline No & localization & voivodeship & $\begin{array}{l}\text { House type } \\
\text { according } \\
\text { to Kloeppel } \\
\text { statistics }\end{array}$ & $\begin{array}{l}\text { date of } \\
\text { construction }\end{array}$ & remarks \\
\hline 6 & $\begin{array}{l}\text { Nowa Kościel- } \\
\text { nica } 64\end{array}$ & Pomeranian & II & $\begin{array}{l}\text { mid- } 18^{\text {th }} \\
\text { century }\end{array}$ & $\begin{array}{l}\text { technical condition: good, after } \\
\text { general renovation in } 2013 \text {, } \\
\text { uninhabited house, one-third } \\
\text { of the building is adapted for } \\
\text { residential purposes, the rest is } \\
\text { used as a warehouse }\end{array}$ \\
\hline 7 & $\begin{array}{l}\text { Klecie } 4 \\
\text { (Fig. 1a) }\end{array}$ & Pomeranian & I & around 1750 & $\begin{array}{l}\text { technical condition: sufficient, } \\
\text { residential house, village } \\
\text { lounge on the ground floor }\end{array}$ \\
\hline 8 & $\begin{array}{l}\text { Stalewo } 14 \\
\text { (Fig. 1c) }\end{array}$ & $\begin{array}{l}\text { Warmia - } \\
\text { Masuria }\end{array}$ & II-III & 1751 & $\begin{array}{l}\text { technical condition: sufficient, } \\
\text { uninhabited house, put up } \\
\text { for sale }\end{array}$ \\
\hline 9 & $\begin{array}{l}\text { Steblewo 15/17 } \\
\text { (Fig. 6c,d) }\end{array}$ & Pomeranian & III & $\begin{array}{l}\text { 2nd half of } \\
\text { XVIII }\end{array}$ & $\begin{array}{l}\text { technical condition: unsatisfac- } \\
\text { tory, residential house }\end{array}$ \\
\hline 10 & $\begin{array}{l}\text { Steblewo 22/24 } \\
\text { (Fig. 6a,b) }\end{array}$ & Pomeranian & II-III & $\begin{array}{l}\text { 2nd half of } \\
\text { XVIII }\end{array}$ & $\begin{array}{l}\text { technical condition: unsatisfac- } \\
\text { tory, residential house }\end{array}$ \\
\hline 11 & Zwierzno 51 & $\begin{array}{l}\text { Warmia - } \\
\text { Masuria }\end{array}$ & III & 1773 & $\begin{array}{l}\text { technical condition: good, } \\
\text { residential house in a Dutch } \\
\text { homestead }\end{array}$ \\
\hline 12 & Różany 28 & $\begin{array}{l}\text { Warmia - } \\
\text { Masuria }\end{array}$ & III & 1777 & $\begin{array}{l}\text { technical condition: good, resi- } \\
\text { dential house in a Dutch home- } \\
\text { stead, currently it is for sale }\end{array}$ \\
\hline 13 & $\begin{array}{l}\text { Różyny, } \\
47-49 \text { Gdańska } \\
\text { Street }\end{array}$ & Pomeranian & III & 1784 & $\begin{array}{l}\text { technical condition: good, } \\
\text { residential house }\end{array}$ \\
\hline 14 & $\begin{array}{l}\text { Markusy } 12 \\
\text { (Fig. 1e) }\end{array}$ & $\begin{array}{l}\text { Warmia - } \\
\text { Masuria }\end{array}$ & III & 1789 & $\begin{array}{l}\text { technical condition of the } \\
\text { house: good, residential build- } \\
\text { ing in a Dutch homestead, } \\
\text { farm buildings underwent } \\
\text { significant destruction }\end{array}$ \\
\hline 15 & $\begin{array}{l}\text { Przemysław } 4 \\
\text { (Fig. 5c) }\end{array}$ & Pomeranian & III & 1789 & $\begin{array}{l}\text { technical condition: very good, } \\
\text { house after complete renova- } \\
\text { tion in } 2005 \text {, now it is a house } \\
\text { for rent }\end{array}$ \\
\hline 16 & $\begin{array}{l}\text { Koszwały, } \\
21 \text { Gdańska } \\
\text { Street (Fig. 1d) }\end{array}$ & Pomeranian & III & 1792 & $\begin{array}{l}\text { technical condition: good, } \\
\text { residential house }\end{array}$ \\
\hline 17 & Myszewko 4a & Pomeranian & III & 1793 & $\begin{array}{l}\text { technical condition: good, } \\
\text { residential house }\end{array}$ \\
\hline 18 & Żuławki 32-33 & Pomeranian & III & 1797 & $\begin{array}{l}\text { technical condition: sufficient, } \\
\text { residential house }\end{array}$ \\
\hline 19 & Rozgart 13a & $\begin{array}{l}\text { Warmia - } \\
\text { Masuria }\end{array}$ & I & end of XVIII & $\begin{array}{l}\text { technical condition: good, } \\
\text { residential house }\end{array}$ \\
\hline 20 & Zwierzno 39 & $\begin{array}{l}\text { Warmia - } \\
\text { Masuria }\end{array}$ & III & end of XVIII & $\begin{array}{l}\text { technical condition: good, } \\
\text { residential house }\end{array}$ \\
\hline
\end{tabular}




\begin{tabular}{|c|c|c|c|c|c|}
\hline No & localization & voivodeship & $\begin{array}{l}\text { House type } \\
\text { according } \\
\text { to Kloeppel } \\
\text { statistics }\end{array}$ & $\begin{array}{l}\text { date of } \\
\text { construction }\end{array}$ & remarks \\
\hline 21 & $\begin{array}{l}\text { Nowy Dwór } \\
\text { Gdański, } \\
74 \text { Morska } \\
\text { Street }\end{array}$ & Pomeranian & III & 1800 & $\begin{array}{l}\text { technical condition: good, } \\
\text { residential house }\end{array}$ \\
\hline 22 & $\begin{array}{l}\text { Mikoszewo } 55 \\
\text { (Fig. 5b) }\end{array}$ & Pomeranian & III & 1800 & $\begin{array}{l}\text { technical condition: very good, } \\
\text { reconditioned in 2017, residen- } \\
\text { tial house }\end{array}$ \\
\hline 23 & Krzywe Koło 36 & Pomeranian & III & early XIX & $\begin{array}{l}\text { technical condition: very good, } \\
\text { the building houses the Caritas } \\
\text { Center of the Gdańsk Arch- } \\
\text { diocese }\end{array}$ \\
\hline 24 & Lubieszewo 29 & Pomeranian & III & early XIX & $\begin{array}{l}\text { technical condition: good, resi- } \\
\text { dential house, part of the build- } \\
\text { ing is used as a guesthouse }\end{array}$ \\
\hline 25 & $\begin{array}{l}\text { Orłowo, } \\
1 \text { Wspólna } \\
\text { Street }\end{array}$ & Pomeranian & III & 1802 & $\begin{array}{l}\text { technical condition: good, } \\
\text { currently uninhabited }\end{array}$ \\
\hline 26 & $\begin{array}{l}\text { Orłowo, } \\
66 \text { Żuławska } \\
\text { Street (Fig. 5a) }\end{array}$ & Pomeranian & III & 1802 & $\begin{array}{l}\text { technical condition: very good, } \\
\text { after complete renovation } \\
\text { 2013-2018, residential house }\end{array}$ \\
\hline 27 & $\begin{array}{l}\text { Marynowy, } \\
\text { 19/19a } \\
\text { Podcieniowa } \\
\text { Street (Fig. 5d) }\end{array}$ & Pomeranian & III & 1803 & $\begin{array}{l}\text { technical condition: very good, } \\
\text { house after general renovation } \\
\text { in } 2012 \text {, residential house, } \\
\text { part of the house intended as } \\
\text { a guest house for tourists }\end{array}$ \\
\hline 28 & Żuławki 64 & Pomeranian & III & 1803 & $\begin{array}{l}\text { technical condition: very good, } \\
\text { renovated in 2014, residential } \\
\text { house }\end{array}$ \\
\hline 29 & $\begin{array}{l}\text { Marynowy, } \\
70 / 70 \mathrm{a} \\
\text { Nowodworska } \\
\text { Street }\end{array}$ & Pomeranian & III & 1804 & $\begin{array}{l}\text { technical condition: sufficient, } \\
\text { residential house }\end{array}$ \\
\hline 30 & Kępniewo 36 & $\begin{array}{l}\text { Warmia - } \\
\text { Masuria }\end{array}$ & III & 1810 & $\begin{array}{l}\text { technical condition: sufficient, } \\
\text { residential house }\end{array}$ \\
\hline 31 & Pordenowo 36 & Pomeranian & III & 1811 & $\begin{array}{l}\text { technical condition: good, } \\
\text { residential house }\end{array}$ \\
\hline 32 & Bystrze 5/7 & Pomeranian & III & 1819 & $\begin{array}{l}\text { technical condition: sufficient, } \\
\text { residential house }\end{array}$ \\
\hline 33 & $\begin{array}{l}\text { Nowy Staw, } \\
11 \text { Gdańska } \\
\text { Street }\end{array}$ & Pomeranian & III & 1820 & $\begin{array}{l}\text { technical condition: good, } \\
\text { residential house }\end{array}$ \\
\hline 34 & $\begin{array}{l}\text { Nowa } \\
\text { Cerkiew } 12\end{array}$ & Pomeranian & III & 1820 & $\begin{array}{l}\text { technical condition: sufficient, } \\
\text { residential house }\end{array}$ \\
\hline
\end{tabular}


Analysis of the state of preservation the historic arcaded houses in Vistula Delta...

\begin{tabular}{|c|c|c|c|c|c|}
\hline No & localization & voivodeship & $\begin{array}{l}\text { House type } \\
\text { according } \\
\text { to Kloeppel } \\
\text { statistics }\end{array}$ & $\begin{array}{l}\text { date of } \\
\text { construction }\end{array}$ & remarks \\
\hline 35 & Żuławki 6 & Pomeranian & III & 1825 & $\begin{array}{l}\text { technical condition: very good, } \\
\text { residential house }\end{array}$ \\
\hline 36 & Rybina 12 & Pomeranian & III & $\begin{array}{l}\text { 1st quarter } \\
\text { of XIX }\end{array}$ & $\begin{array}{l}\text { technical condition: very good, } \\
\text { house after renovation in 2017, } \\
\text { residential house }\end{array}$ \\
\hline 37 & $\begin{array}{l}\text { Lasowice } \\
\text { Wielkie } 12\end{array}$ & Pomeranian & III & 1837 & $\begin{array}{l}\text { technical condition: sufficient, } \\
\text { uninhabited house }\end{array}$ \\
\hline 38 & $\begin{array}{l}\text { Nowa } \\
\text { Kościelnica } \\
50 / 51\end{array}$ & Pomeranian & III & 1840 & $\begin{array}{l}\text { technical condition: good, } \\
\text { residential house }\end{array}$ \\
\hline 39 & Osice 20 & Pomeranian & III & 1844 & $\begin{array}{l}\text { technical condition: sufficient, } \\
\text { residential house }\end{array}$ \\
\hline 40 & $\begin{array}{l}\text { Orłowo, } \\
11 \text { Mennonicka } \\
\text { Street }\end{array}$ & Pomeranian & III & 1847 & $\begin{array}{l}\text { technical condition: good, } \\
\text { residential house in a Dutch } \\
\text { homestead }\end{array}$ \\
\hline 41 & $\begin{array}{l}\text { Gniazdowo } \\
28 / 29\end{array}$ & Pomeranian & III & $\begin{array}{l}1 \text { st half } \\
\text { of XIX }\end{array}$ & $\begin{array}{l}\text { technical condition: good, } \\
\text { residential house }\end{array}$ \\
\hline 42 & $\begin{array}{l}\text { Mikoszewo } 68 \\
\text { (Fig. 1f) }\end{array}$ & Pomeranian & III & mid of XIX & $\begin{array}{l}\text { technical condition: good, } \\
\text { residential house }\end{array}$ \\
\hline 43 & Żuławki 75 & Pomeranian & III & 1859 & $\begin{array}{l}\text { technical condition: very good, } \\
\text { residential house }\end{array}$ \\
\hline
\end{tabular}




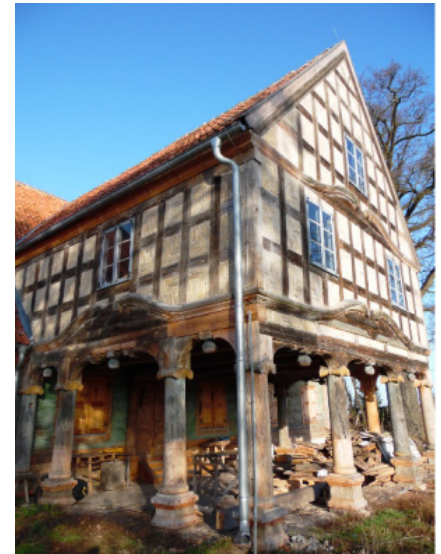

a)

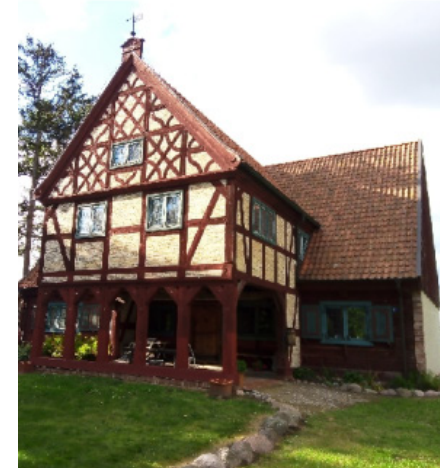

c)

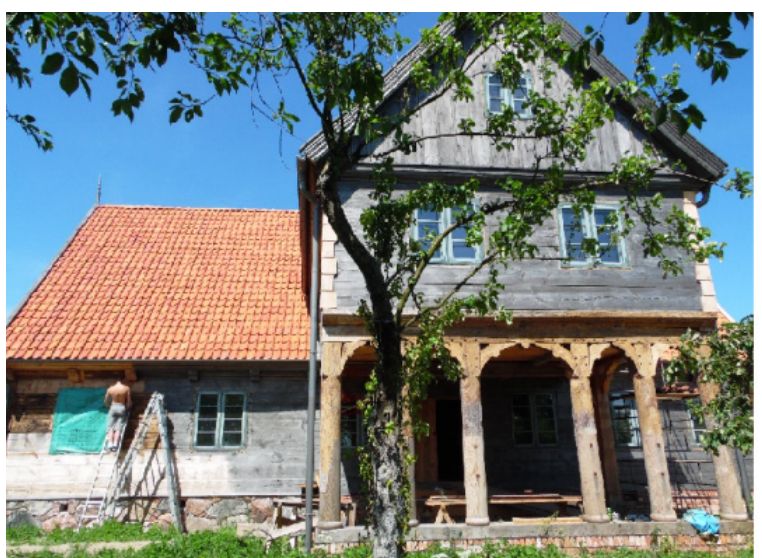

b)

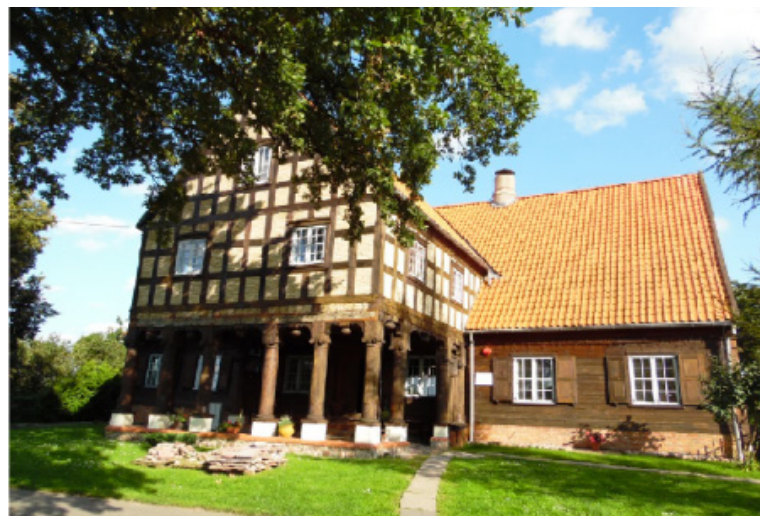

d)

Fig. 5. Arcaded houses in: a) Orłowo no. 66, during construction and conservation works in 2015, b) Mikoszewo no. 55, during construction and conservation works in 2017, c) Przemysław no. 4, d) Marynowy no. 19 / 19a (photo by the author)

Until 2020, 43 arcaded houses from the Żuławy Wiślane area, entered in the register of monuments, have survived. Most of them are located in the Pomeranian Voivodeship 35 houses $(81.40 \%)$, the remaining $8(18.60 \%)$ are located in the Warmia - Masuria Voivodeship (graph 1). 


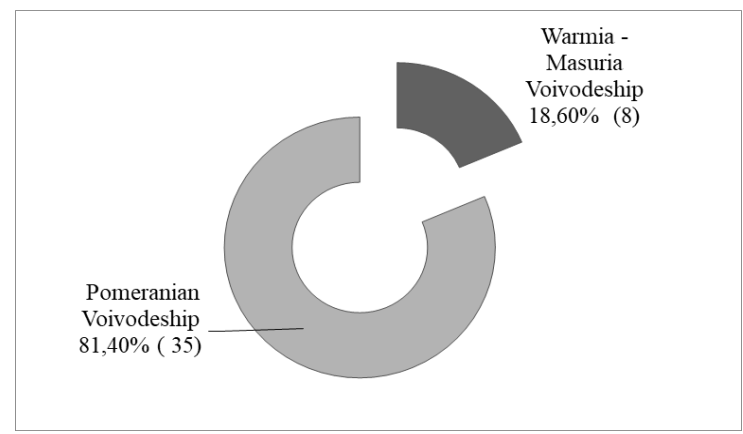

Graph 1. The number of arcaded houses in the Voivodeships: Pomeranian and Warmia - Masuria (author's work)

The least numerous group of preserved monuments are houses: type I - 3 houses $6.98 \%$ (Gdańsk Lipce, Klecie No. 4, Rozgart No. 13a), type II - 3 houses 6.98\% (Miłocin No. 8, Trutnowy No. 7, Nowa Kościelnica No. 64) and type II-III 2 houses 4.65\% (Stalewo No. 14, Steblewo No. 22/24). Type III houses are the most numerous group - 35 buildings $81.40 \%$ (graph 2).

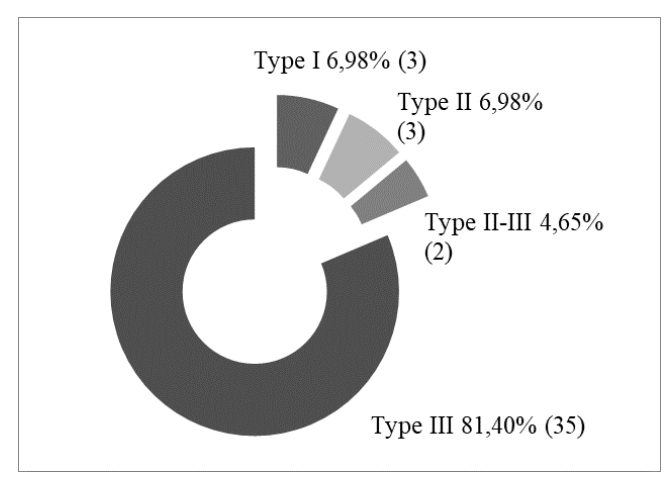

Graph 2. The number of preserved arcaded houses - types division (author's study)

12 houses $(27.91 \%)$ are in a very good technical condition, 19 houses are in a good condition (44.19\%), 10 houses are in sufficient condition $(23.26 \%), 2$ houses are in insufficient condition (4.65\%) - monuments in Steblewo (Fig. 6) (Graph 3). 


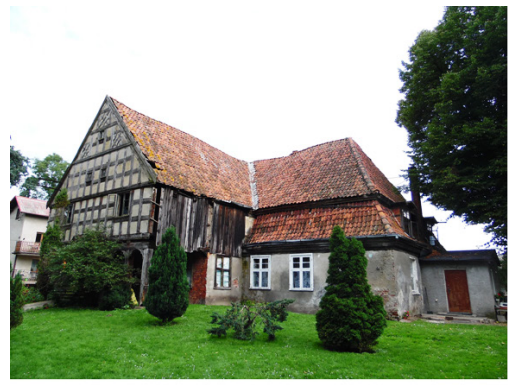

a)

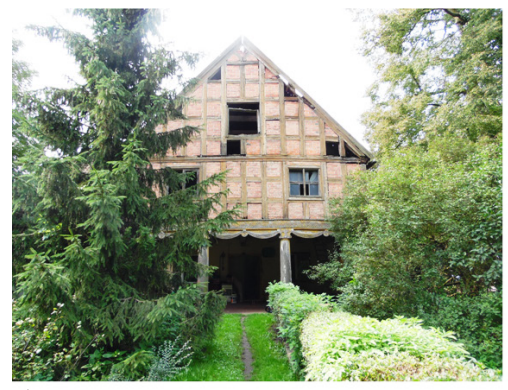

c)

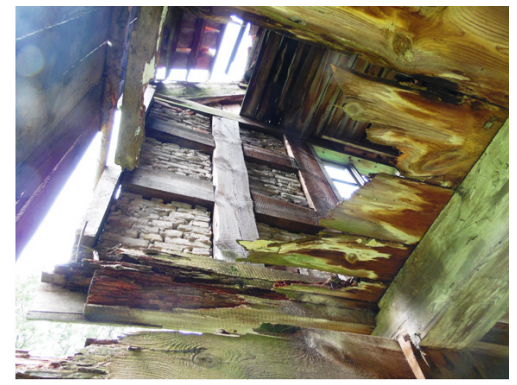

b)

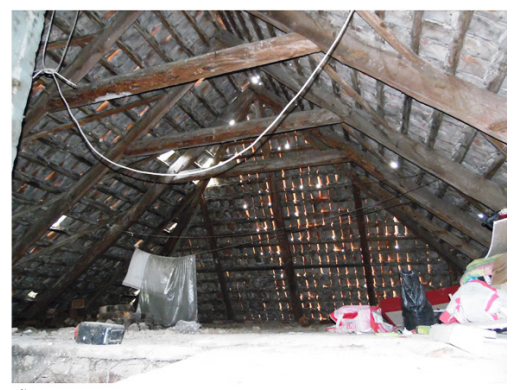

d)

Fig. 6. Houses in: a) Steblewo 22/24, b) Steblewo 22/24 the catastrophic condition of the gable wall of the portico, c) Steblewo 15/17, d) Steblewo 15/17 leaking roofing (photo by the author)

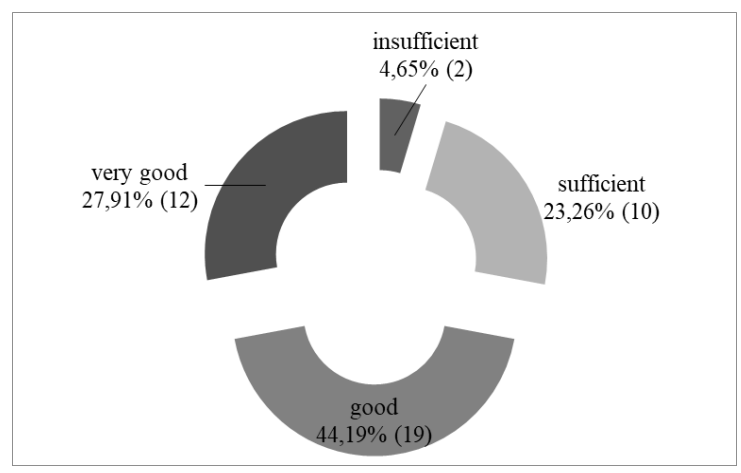

Graph 3. Technical condition of arcaded houses, as of 2020 (author's study)

Only one house from the $17^{\text {th }}$ century $(2.33 \%), 21$ houses from the $18^{\text {th }}$ century $(48.84 \%)$ and 21 from the $19^{\text {th }}$ century $(48.84 \%$ ) (graph 4 ) have survived to the present day. 


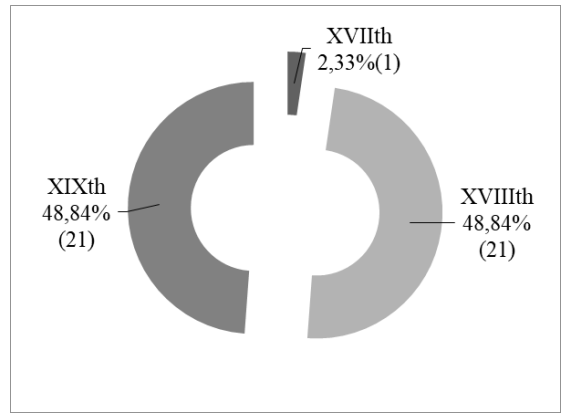

Graph 4. Age of arcaded houses (author's work)

31 houses $(72.09 \%)$ have a residential function, 5 preserved buildings $(11.63 \%)$ have an additional role (Trutnowy 7, Miłocin 8, Klecie 4, Lubieszewo 29, Marynowy 19 / 19a). Four houses $(9.30 \%)$ are uninhabited (Nowa Kościelnica 64, Stalewo 14, Orłowo 1, Lasowice Wielkie 12). Three houses (6.98\%) have a new function: Gdańsk Lipce - hostel, Przemysław 4 - guesthouse, Krzywe Koło 36 - Caritas Center (graph 5).

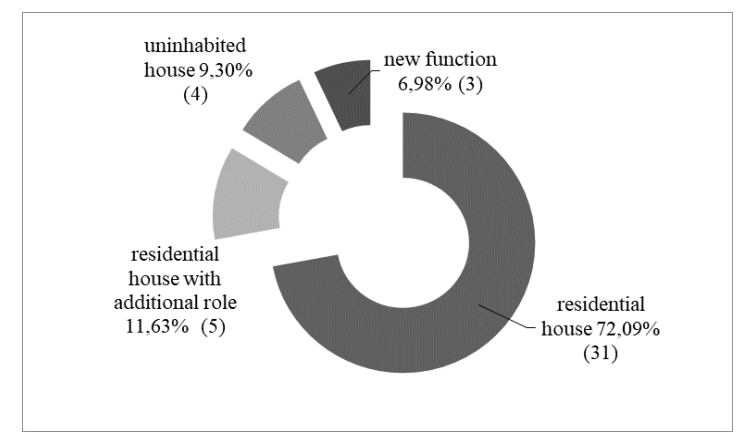

Graph 5. The function of the preserved arcaded houses (author's work)

\section{Conclusions}

Only 43 historic buildings, which are listed in the National Inventory of Historical Monuments, have survived to the present day.

This number is likely to decrease within a few years. Two houses in Steblewo require immediate construction and conservation works. Their technical condition is insufficient. Lack of adequate funds for repairs and little involvement of the owners in saving them will result in the loss of more monuments from the $18^{\text {th }}$ century.

The destruction of the house in Izbiska confirms that the process of degradation of arcaded houses is progressing.

A significant part of the preserved monuments of 31 houses $(72.10 \%)$ is in good or very good technical condition. This is due to the general renovations in some facilities (Table 1), which saved them from destruction. The owners showed determination in obtaining funding and properly carrying out construction and conservation works. In most cases, a good technical 
condition is a consequence of constant maintenance (Tab. 1). It is worth adding that systematic repairs and renovations do not require large financial outlays. They guarantee a good technical condition of the facility.

The number of preserved arcaded houses from the $18^{\text {th }}$ and $19^{\text {th }}$ centuries is noteworthy, they are equal ( 21 objects).

Most of the houses, 36 of them, which constitutes $83.72 \%$, have retained their original residential function. A much smaller part has a new role or is uninhabited. Houses that are currently unoccupied are used by their owners as warehouses or holiday homes (e.g. houses in Nowa Kościelnica No. 64, Lasowice Wielkie No. 12, Orłowo 1, Stalewo No. 14). Such functions of objects do not cause their destruction or deterioration of their technical condition. The owners care about the monuments and their surroundings.

The above list is the basis for the author's further research on the historic arcaded houses of the Vistula Delta.

\section{Acknowledgements}

The author would like to thank the owners of arcaded houses for their time and the possibility of making photographic documentation.

\section{References}

[1] Tłoczek I., Dom mieszkalny na polskiej wsi. Warszawa: Państwowe Wydawnictwo Nukowe, 1985.

[2] Kopkowicz F., Ciesielstwo polskie. Warsaw: Arkady, 1958.

[3] Stankiewicz J., Zabytki budownictwa i architektury na Żuławach. Rocznik Gdański, t. XV/XVI. Gdańsk: Gdańskie Towarzystwo Naukowe, 1956.

[4] Laskowska K., W żuławskim domu. Elbląg: Wydawnictwo Uran Marzenna Bracka-Kondracka, 2010.

[5] Bertram H. et al., Das Weichsel-Nogat-Delta : Beiträge zur Geschichte seiner landschaftichen Entwickelung, vorgeschichtlichen Besiedelung und bäuerlichen Haus- und Hofanlage. Danzig: Danziger Verlags-Gesellschaft, 1924.

[6] Lipińska B., "Drewniane budownictwo na Żuławach Wiślanych - ginący symbol tożsamości unikatowego krajobrazu wsi," in Budownictwo drewniane w gospodarce przestrzennej europejskiego dziedzictwa, Białystok: Wydawnictwo Wyższej Szkoły Finansów i Zarządzania w Białymstoku, 2004, pp. 249-256.

[7] Koperska-Kośmicka M., Żuławskie domy podcieniowe. Przyczyny degradacji i problematyka konserwatorska zabytkowych struktur architektonicznych w środowisku kulturowym Delty Wisły. Ph.D. dessideration, Faculty of Architecure, Gdańsk University of Technology, 2014.

[8] Kloeppel O., Die bäuerliche Haus-, Hof-und Siedlungsanlage im Weichsel- Nogat- Delta. Sonderdruck Aus: Bertram - La Baume-Kloeppel, Das Weichsel-Nogat-Delta. Danzig: W. F. Burau, 1924.

[9] Kulke E., Die Laube als ostgermanisches Baumerkmal. München: Hoheneichen-Verlag, 1939.

[10] Heise J., Die Bau Und Kunstdenkmaler der Provinz Westpreussen, H.11 Landkreis. Danzig, Comissions - 1884-1887. Danzig: Verlag von Th. Berling, 1887.

[11] Schmid B., Die denkmalpflege in Westpreussen 1804-1910. Danzig: Verlag des Provinzialverbandes von Westpreußen, 1910.

[12] Schmid B., Die Bau - und Kunstdenkmäler des Kreises Marienburg (The architectural and art monuments of the Marienburg district). Danzig: Verlag des Provinzial-verbandes von Westpreuszen. Kommissionsverlag von A. W. Kafemann G.M.B.H., 1919.

[13] Krzyżanowski L., Żuławskie domy podcieniowe. Dokumentacja historyczna. Gdańsk: PPKZ, 1968. 
[14] Lipińska B., Żuławy Wiślane - ochrona i ksztaltowanie zabytkowego krajobrazu. Ph.D. dissertation, Politechnika Krakowska, t I-III, Kraków 1986.

[15] Koperska-Kośmicka M., Dom podcieniowy na Żuławach. Gdańsk: Instytut Kszaubski w Gdańsku, 2020.

[16] Niezabitowska E., Metody i techniki badawcze w architekturze. Gliwice: Wydawnictwo Politechniki Śląskiej, 2014.

[17] Cruz H. et al., "Guidelines for On-Site Assessment of Historic Timber Structures Guidelines for On-Site Assessment of Historic Timber Structures," International Journal of Architectural Heritage, vol. 9, no. 3, (2015), pp. 277-289. https://doi.org/10.1080/15583058.2013.774070

[18] National Institute of Cultural Heritage, Rejestr zabytków województwa pomorskiego. Available: www. nid.pl/pl/Informacje_ogolne/Zabytki_w_Polsce/rejestr-zabytkow/zestawienia-zabytkow-nieruchomych/ [Access: 5 Jan 2016]

[19] National Institute of Cultural Heritage, Rejestr zabytków województwa warmińsko mazurskiego, Available: www.nid.pl/pl/Informacje_ogolne/Zabytki_w_Polsce/rejestr-zabytkow/zestawienia-zabytkownieruchomych/ [Access: 5 Jan 2016]

[20] National Institute of Cultural Heritage, Explore the most beautiful Polish monuments. Available: www.zabytek.pl [Access: 5 Jan 2020]

[21] Kondracki J., Geografia regionalna Polski. Warszawa: Wydawnictwo Naukowe PWN, 2002.

[22] Augustowski B., Żuławy Wiślane. Gdańsk: Gdańskie Towarzystwo Naukowe, 1976.

[23] Act on Monument Protection and Care, Journal of Laws of The Republic of Poland 2003, no. 162. Available: https://isap.sejm.gov.pl/isap.nsf/DocDetails.xsp?id=WDU20031621568

[24] Zybała T., "Wpływ stanu zachowania materiału konstrukcyjnego na nośność zabytkowych drewnianych słupów, w żuławskich domach podcieniowych, z XVIII i XIX wieku”, Budownictwo i Architektura, vol. 16, no. 4, (2017), pp. 77-94. https://doi.org/10.24358/Bud-Arch_17_163_08

[25] Zybała T., "The wooden rafter framing of Żuławy arcaded houses of type III - research, state of preservation and analysis," Budownictwo i Architektura, vol. 18, no. 2, (Dec. 2019), pp. 093-110. https://doi.org/10.35784/bud-arch.564

[26] Zybała T., "Techniczne problemy konstrukcji ścian szkieletowych na przykładzie zabytkowego domu podcieniowego w Gdańsku Lipcach”, Przestrzeń, Ekonomia, Społeczeństwo, vol. 11/I, (2017), pp. 49-60.

[27] National Institute of Cultural Heritage, Rejestr zabytków województwa pomorskiego. Available: nid. pl/pl/Informacje_ogolne/Zabytki_w_Polsce/rejestr-zabytkow/zestawienia-zabytkow-nieruchomych/ [Access: 1 Jul 2021]

[28] National Institute of Cultural Heritage, Rejestr zabytków województwa warmińsko mazurskiego. Available: nid.pl/pl/Informacje_ogolne/Zabytki_w_Polsce/rejestr-zabytkow/zestawienia-zabytkow-nieruchomych/ [Access: 1 Jul 2021]

[29] Ciołek G., "Chałupy podcieniowe na Pomorzu”, Biuletyn Historii Sztuki i Kultury, vol. VII(2), (1939).

[30] Łęga W., Ziemia malborska. Kultura ludowa. Toruń, Warszawa: Instytut Popierania Nauki, Kasa im. Mianowskiego, 1933.

[31] Cinkusz M., Architecture and Building Historical Monument record - The arcaded house in Mitocin. The National Heritage Board of Poland in Gdańsk, sygnature: 2173, 1983.

[32] Cinkusz M., Architecture and Building Historical Monument record - The arcaded house in Trutnowy no 4. The National Heritage Board of Poland in Gdańsk, sygnature: 2179, 1984.

[33] Krzyżanowski L., Gdańsk - Lipce. The arcade house. Report on the conservation work-1960. The National Heritage Board of Poland in Gdańsk, sygnature: ZN/1066, 1960.

[34] Ważny T., "Określenie wieku zabytków architektury z Pomorza Wschodniego przy zastosowaniu metody dendrochronologicznej”, Ochrona Zabytków, vol. 45/4 (179), (1992), pp. 354-359. 
